\title{
Nuclear Thyroxine and Triiodothyronine Receptors in Human Mononuclear Cells in Diabetes Mellitus
}

\author{
J. Kvetny \\ Department of Clinical Chemistry and Internal Medicine M, Odense University Hospital, Odense, Denmark
}

\begin{abstract}
Summary. The number of nuclear thyroxine $\left(\mathrm{T}_{4}\right)$ or triiodothyronine $\left(T_{3}\right)$ receptors and the serum values of thyroxine, triiodothyronine, reverse triiodothyronine and TSH were investigated in 13 patients with Type 1 (insulin-dependent) diabetes (group 1), in 10 patients with Type 2 (non-insulin-dependent) diabetes (group 2) and in age and weight matched non-diabetic subjects. All patients were clinically euthyroid, although serum $T_{3}$ was low and reverse $T_{3}$ high in group 1 compared with the non-diabetic subjects. The Type 1 diabetic patients had evidence of poor metabolic control because of weight loss and high glycosylated haemoglobin levels. The maximal specific nuclear binding capacities for $T_{4}$ $\left(1.8 \times 10^{-16} \mathrm{~mol}_{4} / 10 \mu \mathrm{g} D \mathrm{DNA}\right)$ and $\mathrm{T}_{3}\left(1.4 \times 10^{-16} \mathrm{~mol}\right.$ $\mathrm{T}_{3} / 10 \mu \mathrm{g}$ DNA) were increased in group 1 compared with the normal subjects $\left(\mathrm{T}_{4}: 1.1 \times 10^{-16} \mathrm{~mol} \mathrm{~T}_{4} / 10 \mu \mathrm{g} \mathrm{DNA}, \mathrm{p}<0.010\right.$, $\mathrm{T}_{3}: 0.9 \times 10^{-16} \mathrm{~mol} \mathrm{~T}_{3} / 10 \mu \mathrm{g}$ DNA, $\left.\mathrm{p}<0.05\right)$, whereas the nu-
\end{abstract}

clear binding affinity for $T_{4}\left(K_{a}=1.5 \times 10^{9} 1 / \mathrm{mol}\right)$ and $T_{3}$ $\left(5.1 \times 10^{9} \mathrm{l} / \mathrm{mol}\right)$ was similar to that of the normal subjects $\left(\mathrm{T}_{4}\right.$, $\left.\mathrm{K}_{\mathrm{a}}=2.0 \times 10^{9} \mathrm{l} / \mathrm{mol} ; \mathrm{T}_{3}, \mathrm{~K}_{\mathrm{a}}=5.6 \times 10^{9} \mathrm{l} / \mathrm{mol}\right)$. In contrast, neither the nuclear binding of $\mathrm{T}_{4}\left(1.0 \times 10^{-16} \mathrm{~mol} \mathrm{~T}_{4} / 10 \mu \mathrm{g}\right.$ DNA) and $\mathrm{T}_{3}\left(1.1 \times 10^{-16} \mathrm{~mol} \mathrm{~T}_{3} / 10 \mu \mathrm{g} \mathrm{DNA}\right)$ nor the binding affinity for $\mathrm{T}_{4}\left(\mathrm{~K}_{\mathrm{a}}=3.3 \times 10^{9} \mathrm{l} / \mathrm{mol}\right)$ and $\mathrm{T}_{3}\left(\mathrm{~K}_{\mathrm{a}}=3.9 \times 10^{9}\right.$ $1 / \mathrm{mol}$ ) in group 2 differed from those of the non-diabetic subjects. In conclusion, nuclear $T_{4}$ and $T_{3}$ receptor number in cells from patients with poorly controlled Type 1 diabetes was raised compared with normal subjects. This increase may have been responsible for the euthyroidism in these patients in whom the serum $T_{3}$ was low. In contrast, cellular binding of $T_{4}$ and $T_{3}$ appeared normal in the Type 2 diabetic subjects.

Key words: $T_{4}$ receptors, $T_{3}$ receptors, Type 1 and Type 2 diabetes.
Various abnormalities of thyroid function have been described in diabetes mellitus, including the depression of total serum triiodothyronine $\left(\mathrm{T}_{3}\right)$ and thyroxine $\left(\mathrm{T}_{4}\right)$ concentrations in untreated patients [1]. However, decreased circulating concentrations of $T_{4}$ and $T_{3}$ do not necessarily reflect decreased hormone concentrations at the receptor site. As the magnitude of effect of thyroid hormones is directly correlated with the quantity of iodothyronine bound specifically to cell nuclei in various organs, we have determined the relationship between the concentrations of thyroid hormones in the blood and nuclear $T_{4}$ and $T_{3}$ receptor concentration in patients with diabetes mellitus.

\section{Materials and Methods}

\section{Patients}

Two groups of diabetic patients and two groups of non-diabetic subjects were studied. Group 1 comprised 13 patients with Type 1 diabetes, who were all judged to require insulin on clinical grounds. The duration of their diabetes ranged from 4 weeks to 10 years. At the time of investigation all patients were underweight and had elevated levels of glycosylated haemoglobin, suggesting poor metabolic control. On the day of investigation and the two previous days, ketone bodies were present in the urine, although none of the patients was acidotic as judged by serum bicarbonate levels. Group 2 consisted of ten patients with Type 2 diabetes of duration from 1 to 10 years (Table 1 ). No patient had a history of thyroid disease. The control groups comprised eight subjects matched with the patients in group 1 and five subjects matched with the patients in group 2 with regard to weight and age (Table 1). All the control subjects were without any signs of diabetes or thyroid disease. Blood samples were drawn for the cellular experiments, total serum thyroxine $\left(\mathrm{T}_{4}\right)$, total serum triiodothyronine $\left(T_{3}\right), T_{3}$ uptake ratio, serum reverse triiodothyronine $\left(\mathrm{rT}_{3}\right)$, serum thyrotropin (TSH), serum thyroglobulin antibodies and blood glycosylated haemoglobin $A_{1}$ after informed consent. A TRH test was performed in ten patients with diabetes (five with Type 1 and five with Type 2 ) and 10 control subjects (five in each group).

\section{Methods}

Commercially available methods were used for the determinations of serum $\mathrm{T}_{4}$ (Clinical Assays Gammacoat $\mathrm{T}_{4}$ kit, Travenol Lab., Cambridge, UK), serum $T_{3}$ (Amerlex $T_{3}$ RIA kit, Amersham International, Amersham, UK), $T_{3}$ uptake (Clinical Assays Gammacoat $T_{3}$ uptake kit, Travenol Lab., Cambridge, UK), TSH (Normal Human Serum TSH RIA kit, Diagnostic Products Cooperation, Los Angeles, USA), reverse $T_{3}$ (Medilab, Copenhagen, Denmark), thyroglobulin antibod- 
Table 1. Clinical and biochemical data from the subjects studied

\begin{tabular}{|c|c|c|c|c|c|c|}
\hline & $\begin{array}{l}\text { Age } \\
\text { range } \\
\text { (years) }\end{array}$ & 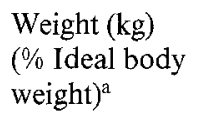 & $\begin{array}{l}\text { Glycosylated } \\
\text { haemoglobin } \\
(\%)\end{array}$ & $\begin{array}{l}\text { Free } \\
\text { thyroxine } \\
\text { index }\end{array}$ & $\begin{array}{l}\text { Serum } \\
\text { triiodothyronine } \\
(\mathrm{nmol} / 1)\end{array}$ & $\begin{array}{l}\text { Serum reverse } \\
\text { triiodothyronine } \\
(\mathrm{nmol} / 1)\end{array}$ \\
\hline $\begin{array}{l}\text { Control group } 1 \\
(n=13)\end{array}$ & $20-30$ & $\begin{array}{l}75.3 \pm 2.7 \\
(+1 \pm 1 \%)\end{array}$ & $5.0 \pm 1.0$ & $103.0 \pm 16.8$ & $1.80 \pm 0.30$ & $0.43 \pm 0.10$ \\
\hline $\begin{array}{l}\text { Control group } 2 \\
(n=10)\end{array}$ & $52-80$ & $\begin{array}{l}85.5 \pm 5.2 \\
(+2 \pm 2 \%)\end{array}$ & $5.4 \pm 0.4$ & $100.0 \pm 15.3$ & $1.30 \pm 0.42$ & $0.35 \pm 0.05$ \\
\hline
\end{tabular}

Results expressed as mean \pm SD. a Percentage over or underweight compared with ideal weight (Natvig 1956, Oslo) is shown. b $p<$ $0.05 ;{ }^{\mathrm{c}} p<0.010$ compared with the respective control groups; ${ }^{\mathrm{d}}$ Free thyroxine index $=$ serum $\mathrm{T}_{4} \times \mathrm{T}_{3}$ uptake ratio
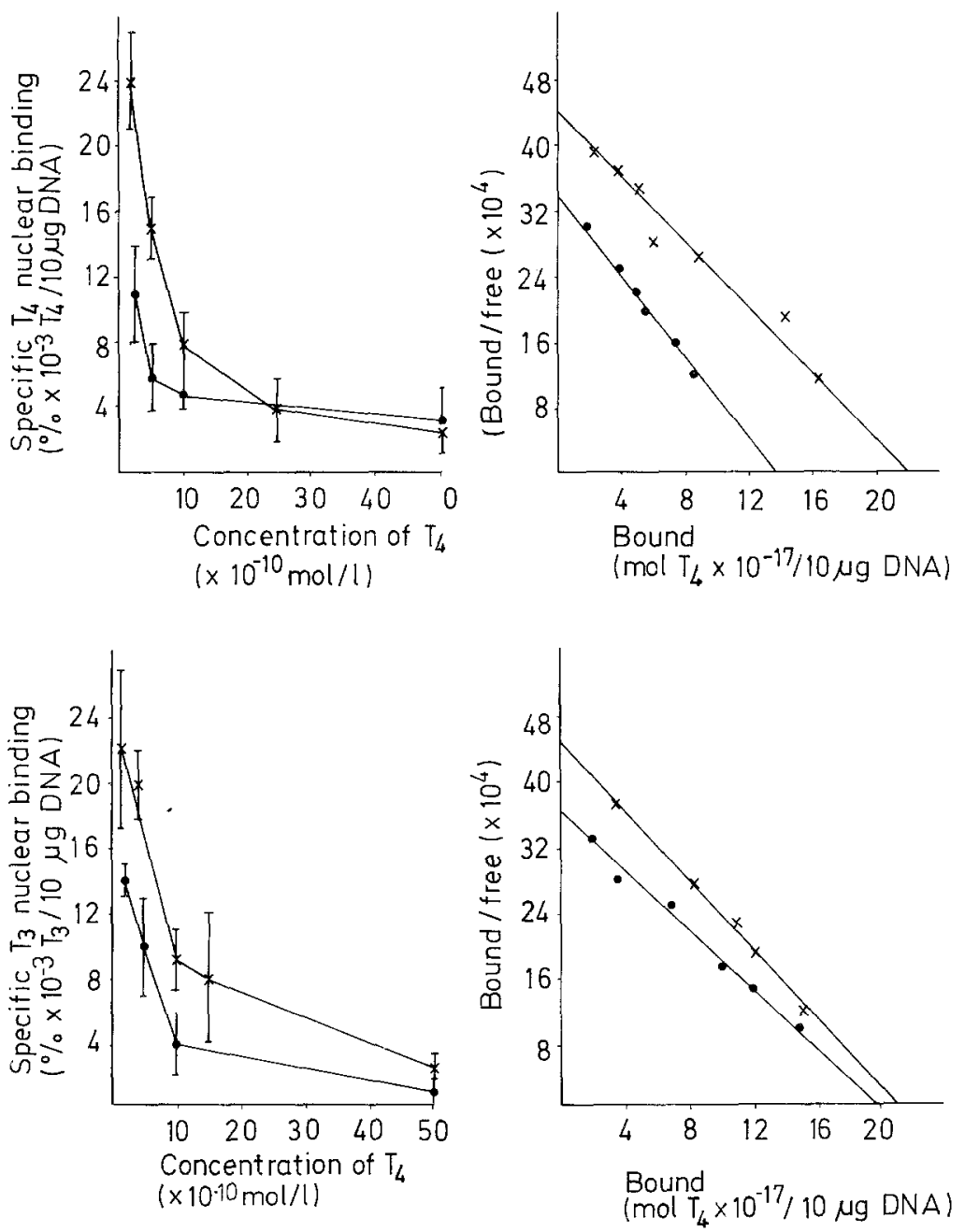

Fig. 1. Specific nuclear binding of ${ }^{125} \mathrm{I}_{-} \mathrm{T}_{4}$ in nuclei from patients with Type 1 diabetes. Left panel: percentage ${ }^{125} \mathrm{I}$ $T_{4}$ specific bound to nuclei from eight patients with Type 1 diabetes $(x-x)$ and to nuclei from eight control subjects (-) with increasing concentrations of ${ }^{125} \mathrm{I}-\mathrm{T}_{4}$ (mean \pm SD). Right panel: representative Scatchard plots of specific nuclear binding of ${ }^{125} I-T_{4}$ to nuclei from a patient with Type 1 diabetes $(x-x)$ and to nuclei from a control subject (

Fig. 2. Specific nuclear binding of ${ }^{125} \mathrm{I}-\mathrm{T}_{3}$ in nuclei from patients with Type 1 diabetes. Left panel: percentage ${ }^{125} I$ $\mathrm{T}_{3}$ specific bound to nuclei from five patients with Type 1 diabetes $(x-x)$ and to nuclei from five control subjects (-) with increasing concentrations of ${ }^{125} \mathrm{I}-\mathrm{T}_{3}$

(mean $\pm \mathrm{SD}$ ). Right panel: representative Scatchard plots of specific nuclear binding of ${ }^{125} \mathrm{I}_{-} \mathrm{T}_{3}$ to nuclei from a patient with Type 1 diabetes $(x-x)$ and to nuclei from a control subject ies (Thymune-T, Wellcome, Beckenham, Kent, UK) and glycosylated haemoglobin $\mathrm{A}_{1}\left(\mathrm{HgA}_{1}\right.$ column test kit, Bio-Rad, Richmond, California, USA).

\section{Isolation of Mononuclear Cells from Blood}

Mononuclear cells were isolated from $100 \mathrm{ml}$ of blood by a modification of the method of Böyum [2]. Blood was diluted with $0.9 \% \mathrm{NaCl}$ and centrifuged at $800 \mathrm{~g}$ for $15 \mathrm{~min}$ in Lymphoprep (NycoMed, Copenhagen, Denmark). The interphase was harvested and washed twice in Hanks solution. This yielded lymphocytes $(80 \%-90 \%)$ and monocytes $(10 \%-20 \%)$ but no erythrocytes or platelets as judged by light microscopy. Judged by the trypan blue exclusion test, $98 \%$ cells were viable after isolation and incubation for $120 \mathrm{~min}$. The number of cells was determined in a Bürker-Türk chamber (Scherf, Marburg, FRG).

\section{Uptake of ${ }^{125} I-T_{4}$ or ${ }^{125} I-T_{3}$ in Mononuclear Cells}

Mononuclear cells and ${ }^{125} \mathrm{I}-\mathrm{T}_{4}$ or ${ }^{125} \mathrm{I}-\mathrm{T}_{3}$ were added to tubes containing $1 \mathrm{ml}$ phosphate buffered Hanks medium ( $\mathrm{pH} \mathrm{7.4).} \mathrm{The} \mathrm{number} \mathrm{of}$ cells in each tube was adjusted to $15 \times 10^{6}$ cells in a final volume 

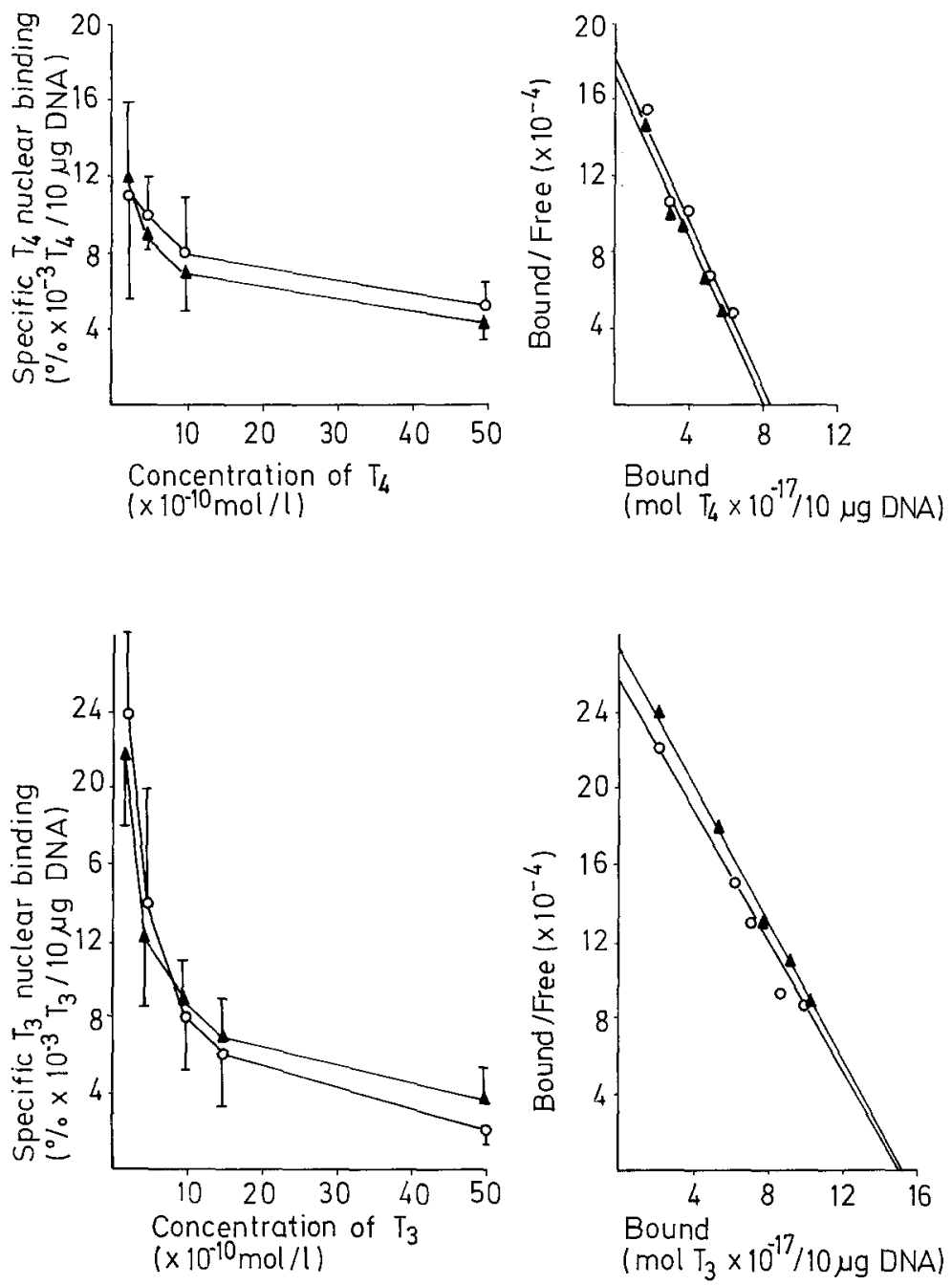

Fig. 3. Specific nuclear binding of ${ }^{125} \mathrm{I}_{-} \mathrm{T}_{4}$ in nuclei from patients with Type 2 diabetes. Left panel: percentage ${ }^{125} \mathrm{I}-$ $\mathrm{T}_{4}$ specific bound to nuclei from five patients with Type 2 diabetes $(\mathrm{O}-\mathrm{O})$ and to nuclei from five control subjects ( (mean \pm SD). Right panel: representative Scatchard plots of specific nuclear binding of ${ }^{125} \mathrm{I}-\mathrm{T}_{4}$ to nuclei from a patient with Type 2 diabetes $(\mathrm{O}-\mathrm{O})$ and to nuclei from a control subject $(\mathbf{\Lambda})$
Fig. 4. Specific nuclear binding of ${ }^{125} \mathrm{I}_{-} \mathrm{T}_{3}$ in nuclei from patients with Type 2 diabetes. Left panel: percentage ${ }^{125} \mathrm{I}-$ $\mathrm{T}_{3}$ specific bound to nuclei from five patients with Type 2 diabetes $(\mathrm{O}-\mathrm{O})$ and to nuclei from five control subjects ( $\Delta-\boldsymbol{\Delta}$ ) with increasing concentrations of ${ }^{125} \mathrm{I}_{-} \mathrm{T}_{3}$ (mean \pm SD). Right panel: representative Scatchard plots of specific nuclear binding of ${ }^{125} \mathrm{I}-\mathrm{T}_{3}$ to nuclei from a patient with Type 2 diabetes $(\mathrm{O}-\mathrm{O})$ ) and to nuclei from a control subject $(\mathbf{\Delta - \mathbf { A }})$
Table 2. Increase of serum TSH after injection of TRH in the diabetic and non-diabetic subjects

\begin{tabular}{llll}
\hline & \multicolumn{3}{l}{ TSH $(\mathrm{mU} / \mathrm{l})$} \\
\cline { 2 - 4 } & $0 \mathrm{~min}$ & $20 \mathrm{~min}$ & $60 \mathrm{~min}$ \\
\hline $\begin{array}{l}\text { Group 1 } \\
\text { (Type 1 diabetes, } n=5)\end{array}$ & $1.1 \pm 0.5$ & $17.9 \pm 5.2^{\mathrm{a}}$ & $9.8 \pm 2.6$ \\
Control group 1 $(n=5)$ & $1.4 \pm 0.3$ & $8.6 \pm 1.9$ & $7.5 \pm 2.7$ \\
Group 2 & $1.1 \pm 0.6$ & $6.2 \pm 2.1$ & $5.3 \pm 1.3$ \\
(Type 2 diabetes, $n=5)$ & & & \\
Control group 2 $(n=5)$ & $1.0 \pm 0.4$ & $5.8 \pm 3.9$ & $5.0 \pm 2.0$ \\
\hline
\end{tabular}

Results expressed as mean $\pm S D$, a $p<0.10$ compared with the nondiabetic group. Reference: serum TSH in euthyroid subjects $<3.0 \mathrm{mU} / 1$

of $1 \mathrm{ml}$. The concentration of ${ }^{125} \mathrm{I}_{-} \mathrm{T}_{4}$ or ${ }^{125} \mathrm{I}-\mathrm{T}_{3}$ varied from $1.5 \times 10^{-10}$ $\mathrm{mol} / 1$ to $5.0 \times 10^{-9} \mathrm{~mol} / 1$. The specific activity of the preparation was $50 \mu \mathrm{Ci} / \mu \mathrm{g}$ (Amersham International, Amersham, UK) and the preparation contained $<3 \%$ free ${ }^{125} \mathrm{I}$ and $<1 \%{ }^{125} \mathrm{I}-\mathrm{T}_{3}$ in the ${ }^{125} \mathrm{I}-\mathrm{T}_{4}$ preparation and $<1 \%{ }^{125} \mathrm{I}-\mathrm{T}_{2}$ in the ${ }^{125} \mathrm{I}-\mathrm{T}_{3}$ preparation. No other iodothyronines could be detected by column chromatography. The cells were incubated at $37^{\circ} \mathrm{C}$ for $90 \mathrm{~min}$. The incubation was terminated by cooling the tubes to $3^{\circ} \mathrm{C}$, as previous experiments had demonstrated that binding at $3^{\circ} \mathrm{C}$ was negligible for up to $18 \mathrm{~h}$.

\section{Isolation of Nuclei}

After incubation, the cells were washed five times in cold Hanks solution and resuspended in $5 \mathrm{mI}$ of cold buffer $(0.25 \mathrm{~mol}$ sucrose, 1.1. $\mathrm{mmol} \mathrm{MgCl}_{2}$ and $20 \mathrm{~mol}$ TRIS/1), $\mathrm{pH} 7.85$, containing $0.5 \%$ triton $\mathrm{x}-100$. This suspension was homogenized for $30 \mathrm{~s}$ in a Potter-Elvehjem homogenizer (Braun, Melsungen, FRG) to enchance the disruption of the cell membrane, and then centrifuged at $1000 \mathrm{~g}$ for $10 \mathrm{~min}$. All procedures were carried out at $0-3{ }^{\circ} \mathrm{C}$. Washing was repeated once with $5 \mathrm{ml}$ buffer. This procedure yielded nuclei that under phase contrast microscopy appeared intact and clean. More than $90 \%$ of the cellular DNA was confined to the nuclear fraction. Finally, $1 \mathrm{ml} 95 \%$ ethanol was added to extract the iodothyronines. The radioactivity in the nuclei and the supernatant was counted in a gamma scintillation counter (Selektronik, Copenhagen, Denmark). DNA was determined by the method of Burton [3].

\section{Determination of Deiodination and Deiodination Products}

Column chromatography was performed on acrylic columns ( $\mathrm{K}$ 15/30, Pharmacia, Uppsala, Sweden) filled with Sephadex G25 medium (Pharmacia), equlibrated with phosphate buffer $(0.02 \mathrm{~mol} / \mathrm{l})$ $(\mathrm{pH} 7.4)$ and $\mathrm{NaOH}(0.1 \mathrm{~mol} / 1), \mathrm{NaCl}(0.005 \mathrm{~mol} / \mathrm{l})$ at a rate of $32 \mathrm{ml} / \mathrm{h}$. Eighteen fractions $(5 \mathrm{ml} /$ fraction) were eluted with phosphate buffer and 32 fractions ( $5 \mathrm{ml} /$ fraction) were eluted with $\mathrm{NaOH} / \mathrm{NaCl}$. For reference, chromatography was carried out with ${ }^{125} \mathrm{I},{ }^{125} \mathrm{I}-\mathrm{T}_{3},{ }^{125} \mathrm{I}-3.3^{\prime} .5^{\prime}-\mathrm{T}_{3}$ and ${ }^{125} \mathrm{I}-3.3^{\prime}-\mathrm{T}_{2}$. 
Table 3. Maximal specific nuclear binding capacities and equilibrium association constants $\left(\mathrm{K}_{\mathrm{a}}\right)$ for nuclear binding of $\mathrm{T}_{4}$ and $\mathrm{T}_{3}$ in the diabetic and non-diabetic groups

\begin{tabular}{|c|c|c|c|c|c|}
\hline & & $\begin{array}{l}\text { Type } 1 \text { diabetes } \\
(n=8)\end{array}$ & $\begin{array}{l}\text { Control group } 1 \\
(n=8)\end{array}$ & $\begin{array}{l}\text { Type } 2 \text { diabetes } \\
(n=5)\end{array}$ & $\begin{array}{l}\text { Control group } 2 \\
(n=5)\end{array}$ \\
\hline $\mathrm{T}_{4}$ binding & $\begin{array}{l}\text { Maximal specific binding capacity } \\
\left(\text { mol } \times 10^{-16} / 10 \mu \mathrm{g} \text { DNA }\right) \\
\mathrm{K}_{\mathrm{a}}\left(\mathrm{X} 10^{9} \mathrm{l} / \mathrm{mol}\right)\end{array}$ & $\begin{array}{l}1.8 \pm 0.4^{\mathrm{a}} \\
1.5 \pm 0.2\end{array}$ & $\begin{array}{l}1.1 \pm 0.2 \\
2.0 \pm 0.6\end{array}$ & $\begin{array}{l}1.0 \pm 0.1 \\
3.3 \pm 1.0\end{array}$ & $\begin{array}{l}1.1 \pm 0.3 \\
2.9 \pm 0.8\end{array}$ \\
\hline $\mathrm{T}_{3}$ binding & $\begin{array}{l}\text { Maximal specific binding capacity } \\
\left(\mathrm{mol} \times 10^{16} / 10 \mu \mathrm{g} \text { DNA }\right) \\
\mathrm{K}_{\mathrm{a}}\left(\mathrm{X} 10^{9} \mathrm{l} / \mathrm{mol}\right)\end{array}$ & $\begin{array}{l}1.4 \pm 0.3^{b} \\
5.1 \pm 2.5\end{array}$ & $\begin{array}{l}0.9 \pm 0.2 \\
5.6 \pm 2.2\end{array}$ & $\begin{array}{l}1.1 \pm 0.3 \\
3.9 \pm 1.2\end{array}$ & $\begin{array}{l}1.2 \pm 0.3 \\
4.3 \pm 2.9\end{array}$ \\
\hline
\end{tabular}

Results expressed as mean $+\mathrm{SD},{ }^{\mathrm{a}} p<0.010,{ }^{\mathrm{b}} p<0.05$ compared with the respective control groups
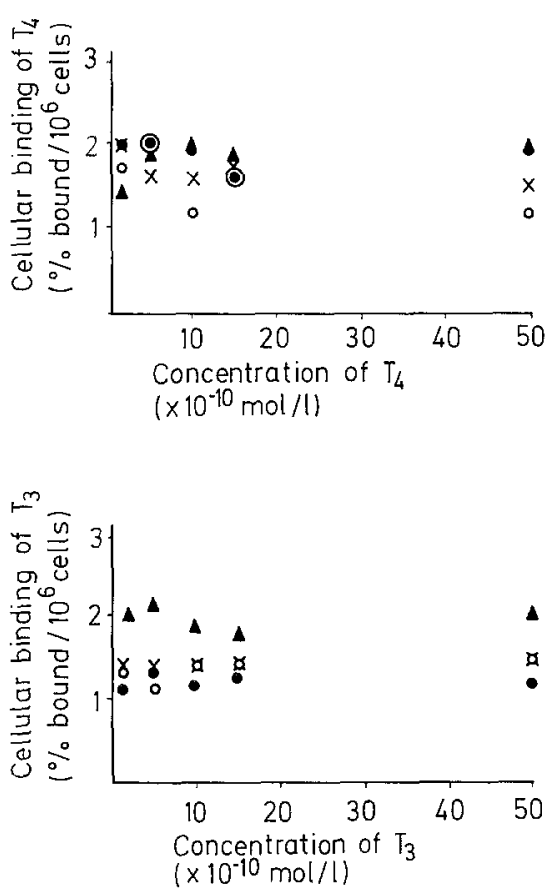

Fig. 5. Total cellular binding of $T_{4}$ and $T_{3}$ in cells from patients with diabetes. Percentage ${ }^{125} \mathrm{I}-\mathrm{T}_{4}$ (top panel) and ${ }^{125} \mathrm{I}-\mathrm{T}_{3}$ (bottom panel) bound to cells from patients with Type 1 diabetes $(x-x, n=8)$ and Type 2 diabetes $(\mathrm{O}-\mathrm{O}, n=5)$ and the respective control groups $(-n=8),(\boldsymbol{\Lambda}-n=5)$, with increasing concentrations of ${ }^{125} \mathrm{I}_{-} \mathrm{T}_{4}$ or ${ }^{125} \mathrm{I}-\mathrm{T}_{3}$. Each point represents mean of eight and five observations respectively, SD for each mean being $<0.5 \%$

\section{Analysis of Binding and Deiodination}

Experimental correction for non-specific binding was accomplished by incubation of duplicate samples, one with radioactive $T_{4}$ or $T_{3}$ alone and one with radioactive $T_{4}$ or $T_{3}$ plus a $10^{6}$-fold excess of nonradioactive $T_{4}$ or $T_{3}$ added $1 \mathrm{~h}$ previously. Specific binding was determined as total binding minus non-specific binding. Degradation of $T_{4}$ during incubation was determined by column chromatography and all results concerning $T_{4}$ binding characteristics were corrected for non- $T_{4}$ radioactivity (endogenous $T_{4}$ to $T_{3}$ conversion).

The method of Scatchard [4] was used to analyze the binding affinity of $T_{4}$ and $T_{3}$ and to estimate the maximal capacity of the high affinity binding sites by means of linear regression analysis. The results of the determinations of maximal specific binding capacity and $k_{a}$ presented, are the means of two separate determinations, the coefficient of variation being $<12 \%$.

Wilcoxon's non-parametric rank sum test was used for statistical analysis.

\section{Results}

Clinical examination of all diabetic patients showed them to be euthyroid. The results of the measurements of the blood hormone levels are shown in Table 1, and the results of the TRH tests in Table 2 . In all subjects, the levels of thyroglobulin antibodies were normal.

\section{Cellular Experiments}

Nuclear uptake of ${ }^{125} \mathrm{I}-\mathrm{T}_{4}$ and ${ }^{125} \mathrm{I}-\mathrm{T}_{3}$ reached a steady state after 90 min incubation. Recovery of the cellular radioactivity during the fractionation procedures was $91.7 \pm 8.0 \%$ (mean $\pm \mathrm{SD}$ ). Deiodination of $\mathrm{T}_{4}$ or $\mathrm{T}_{3}$ during fractionation, extraction and chromatography was negligible, as control experiments showed deiodination of $<2 \%$ of the ${ }^{125} \mathrm{I}-\mathrm{T}_{4}$ after $10 \mathrm{~h}$ at $37^{\circ} \mathrm{C}$. Results from parallel incubation of cells from the same subject varied $<12 \%$. Control experiments, in which intact cells were incubated with ${ }^{125} \mathrm{I}$ had shown that ${ }^{125} \mathrm{I}$ was not taken up in the cells. The DNA content in the nuclei was $10.7 \pm 3.8 \mu \mathrm{g}$ DNA $10^{6}$ nuclei (mean $\pm \mathrm{SD}$ ).

The results from the cellular experiments (Figs. 1 and 2) revealed an increased number of high affinity binding sites for $T_{4}$ and $T_{3}$ in group 1, whereas the binding affinity did not differ from that of the control groups (Table 3 ). Neither the number of high affinity binding sites for $T_{4}$ or $T_{3}$ (Figs. 3 and 4 ) nor the binding affinity for the respective hormones in group 2 differed from those of the control group (Table 3).

The total cellular concentration of both $T_{4}$ and $T_{3}$ was identical in all three groups and constant in the tested concentration range (Fig. 5).

\section{Discussion}

The finding of subnormal total $T_{3}$ levels in both types of diabetic subjects has confirmed the findings of other investigators $[1,5,6]$. Apparently, the low serum levels of $\mathrm{T}_{3}$ are due mainly to a reduction in extrathyroidal conversion of $T_{4}$ to $T_{3}$ [7]. However, in spite of the low serum levels of $T_{3}$, both groups were clinically euthyroid, and basal serum levels of TSH were normal.

The change in circulating thyroid hormone concentrations in diabetic patients clearly resembles those seen 
in caloric deprivation [8], and recently these alterations in serum thyroid hormone indices occurring in diabetes mellitus have been suggested to be a response to the presence of a prolonged period of catabolism [5]. This observation corresponds well with the status of the patients in group 1, in whom weight loss, increased serum levels of $\mathrm{rT}_{3}$ and the presence of urinary ketone bodies suggested a catabolic state. In contrast, there was no evidence of prolonged catabolism in group 2 as judged by the above parameters. The low serum $\mathrm{T}_{3}$ levels in group 2 corresponded with the serum $\mathrm{T}_{3}$ levels found in the age-matched control subjects suggesting a physiologically lower $T_{3}$ level in this older group.

The increased number of nuclear $\mathrm{T}_{4}$ and $\mathrm{T}_{3}$ receptors in group 1, as estimated by the maximal specific binding capacity for $T_{4}$ and $T_{3}$ in mononuclear blood cells, corresponds with the recent report of an increase of nuclear $T_{4}$ and $T_{3}$ receptor number in starved man [9]. In contrast with the present observation, a clear reduction in hepatic nuclear binding of $T_{3}$ in streptozotocintreated rats was reported recently [10]. The explanation for this apparent discrepancy might be afforded by differences in the cellular metabolism of thyroid hormones in man and the rat [11].

The modest increase in the TSH response to TRH injection in group 1 corresponds well with the decreased serum level of $T_{3}$ observed in this group, but might also indicate a decrease of serum $\mathrm{T}_{4}$, as an augmented TSH response to TRH indicates a decrease in serum $T_{4}$ or $T_{3}$ below the normal pituitary set point for feedback [12]. However, the normal basal TSH level could suggest this nuclear $T_{3}$ and/or $T_{4}$ deficiency in the pituitary to be partially compensated. The observed increase in nuclear $T_{4}$ and $T_{3}$ receptor number in group 1 might reflect a compensatory mechanism, which is probably evoked by the intracellular $T_{3}$ deficiency in order to maintain cellular homeostasis. This observation bears on the relationship between nuclear $T_{4}$ and $T_{3}$ receptors. The different binding characteristics between nuclear binding sites for $T_{4}$ and $T_{3}$ also observed in the present investigation suggest separate receptors for $T_{4}$ and $T_{3}$, although recent reports point to close relations between these sites [9]. It is, however, generally accepted that $T_{4}$ is capable of exerting biological effects without conversion to $T_{3}$ [13]. Thus, the increase in both $T_{3}$ and $T_{4}$ receptor number can be explained either by an immeasureable $T_{4}$ deficiency or, what seems more probable, by a parallel increase in both $T_{3}$ and $T_{4}$ receptors, caused by thyroid hormone deficiency.

The normal $T_{4}$ and $T_{3}$ receptor number in cells from group 2, and the normal TRH test results, indicate that the cellular metabolic state is unaltered and is normal.

Alterations in intracellular thyroid hormone concentration and the intracellular transport mechanism can be excluded as the intracellular concentration of $T_{4}$ or $\mathrm{T}_{3}$ after $90 \mathrm{~min}$ incubation did not differ significantly between the groups.
Taken together, our results indicate a difference in nuclear $T_{4}$ and $T_{3}$ binding in patients with Type 1 and Type 2 diabetes. This difference probably reflects a compensated hypometabolic state in Type 1 diabetes related to a catabolic state, and may explain the clinical euthyroidism in group 1 in spite of their low serum $T_{3}$ levels.

Acknowledgements. The author wishes to thank J.F. Rasmussen for technical assistance. This study is supported by the Danish Research Council (512-10768) and by Fonden for lægevidenskabelig forskning i Fyns Amt.

\section{References}

1. Saunders J, Hall SEH, Sönksen PH (1978) Thyroid hormones in insulin requiring diabetes before and after treatment. Diabetologia $15: 20-32$

2. Böyum A (1968) Separation of leucocytes from blood and bone marrow. Scand J Clin Invest 21: 77-89

3. Burton K (1956) The conditions and mechanisms and the Diphenylamin reaction for the colorimetric estimation of deoxyribonucleic acid. Biochem J 62:315-322

4. Scatchard $G$ (1949) The attraction of proteins for small molecules and ions. Ann N Y Acad Sci 51:660-672

5. Alexander CM, Kaptein EM, Lum SMC, Spencer CA, Kumar D, Nicoloff JT (1982) Pattern of recovery of thyroid hormone indices associated with treatment of diabetes mellitus. J Clin Endocrinol Metab 54: 362-366

6. Fujii S, Akai T, Tanaka S, Nakatani K, Kinoshita M, Seki J, Wada M (1981) Thyroid hormone abnormalities in patients with diabetes mellitus. J Endocrinol Invest 4: 71-74

7. Chopra IJ, Wiersinga W, Frank H (1981) Alterations in hepatic monodeiodination of iodothyronines in the diabetic rat. Life Sci 28: $1765-1776$

8. Vaganakis AG, Portnay GI, O'Brian JT, Rudolph M, Arky RA, Ingbar SH, Braverman LE (1977) Effects of starvation on the production and metabolism of thyroxine and triiodothyronine in euthyroid obese patients. J Clin Endocinol Metab 45: 1305-1309

9. Burman MD, Latham KR, Ajua YY, Smallridge RC, Tseng YL, Lukes YG, Maunder R, Wartofsky L (1980) Solubilized nuclear thyroid hormone receptors in circulating human mononuclear cells. J Clin Endocrinol Metab 51: 106-116

10. Wiersinga WM, Frank HJL, Chopra IJ, Solomon PH (1982) Alterations in hepatic nuclear binding of triiodothyronine in experimental diabetes mellitus in rats. Acta Endocrinol 99: 79-85

11. Burman KD, Lukes Y, Wright FD, Wartofsky L (1977) Reduction in hepatic triiodothyronine binding capacity induced by fasting. Endocrinology 101: 1331-1334

12. Sabieri M, Utiger RD (1975) Augmentation of thyrotropin responses to thyrotropin releasing hormone following small decreases in serum thyroid hormone concentrations. J Clin Endocrinol Metab 40: 435-440

13. Chopra II (1981) New insight into metabolism of thyroid hormones. In: Brewer GJ, Eisvogel VP, Grover R, Hirschhorn K, Kety SS, Underfriend S, Uhr JW (eds) Physiopathology of endocrine diseases and mechanisms of hormone action, A.R.Liss, New York, pp 67-80

Received: 31 August 1982

and in final form: 14 March 1983

\section{Dr. J. Kvetny}

Department of Clinical Chemistry

Odense University Hospital

29 , Sdr. Boulevard

DK-5000 Odense

Denmark 